\title{
Specifics of Mediated Memorization Ability of the Adult Internet Users
}

\section{Особливості опосередкованого запам'ятовування у дорослих активних інтернет-користувачів}

\section{Elena Medvedskaia}

Ph.D. in Psychology, Assistant Professor, Assistant Professor of the Department of Psychology, Brest State University named after A.S. Pushkin, Brest (the Republic of Belarus)

ORCID ID: https://orcid.org/0000-0003-2033-510X

Researcher ID: http://www.researcherid.com/rid/M-4006-2019

E-mail: EMedvedskaja@mail.ru

\section{Єлєна Медведська}

Кандидат психологічних наук, доцент, доцент кафедри психології, Брестський державний університет імені О.С. Пушкіна, м. Брест (Білорусь)

\section{ABSTRACT}

The aim of the article is to describe the specifics of a mediated memorization ability of the Internet users (the IU) to memorize new words (familiar/unfamiliar, words that describe certain/abstract concepts).

Methods. The research involved 70 respondents aged 37-53. All the responders have a higher education and work in spheres of intellectual labor (education, culture and healthcare). The respondents were divided into two groups based on their preferences of a coding system: the Internet users (the experimental group, EG) and the Reading Subjects (the control group, CG).

Address for correspondence, e-mail: kpnu_lab_ps@ukr.net Copyright: (C) Medvedskaia Elena

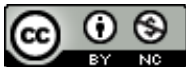


DOI: https://doi.org/10.32626/2227-6246.2021-54

2021. випУСК 54

The pivotal tool in the research was the pictogram technique. It was modified by an extra row. An additional row comprised foreign, unknown words. Instructions, timing and order met the basic requirements of the technique in both cases.

Results of the research. A number of recognized familiar words is equal in both groups. There are statistically significant differences $(p \leq 0.01)$ in recognition of unfamiliar terms. Moreover, there is a significant difference $(p \leq 0.01)$ in recalling abstract concepts in the row of unfamiliar words. In both cases, the reading subjects showed fewer mistakes in recognizing words.

Analyzing the data, no correlation between the age and the quantity of right answers has been detected both in the experimental and control groups.

Conclusions. The hypothesis that the Internet use has deforming consequences for the mediated memorization has been proved. The deformation leads to a deterioration in memorization of new information, especially when it is generalized.

Key words: higher mental functions, mediated memorization, pictogram, active web-users.

\section{Introduction}

The rapid evolution of the Internet, becoming a leading media of the new generation, and the permanently increasing popularity among users of different ages, is gradually leading to a new offline/online or mixed reality. According to a postulate from cultural-historical psychology upon socio-cultural determination of all higher mental functions, new conditions induce new, previously unknown features of the psyche.

Logically, these changes have become a matter of research interest in the past few decades. Despite numerous directions of the research in this field, two main ones can be distinguished. The first direction includes works dedicated to the symptoms and factors of the cyber addiction formation. This type of research started at the beginning of the XX century with the work of $\mathrm{C}$. Young. The second line endeavours to examine various means of online communication and implications caused by it, both in the very communication and the personality of the participants.

(c) Medvedskaia Elena

DOI (article): https://doi.org/10.32626/2227-6246.2021-54.78-92 
DOI: https://doi.org/10.32626/2227-6246.2021-54

2021. випуск 54

The analysis of the Internet use effect on cognitive abilities is a less popular topic for scientific survey. An implicit identification of information and knowledge, widely spread in the scientific community, possibly caused a delusion when owning a «smart» device is equal to the intellectual competence of its owner. Naturally, the representatives of generation $\mathrm{Z}$ got a pivotal role in this type of research. The main impetus for a research were personal observations of M. Prenski (Prenski, 2001), American writer and game designer. He was one of the first to point out changes in cognitive abilities of the adolescent and emergent adults and their discrepancy to a traditional educational practice. The terms «the digital aborigines» and «the digital migrants» introduced by M. Prenski became widespread among scientists.

The results of the studies on cognitive abilities of the emergent adults available at the moment are quite controversial. They confirm and refute common myths at the same time (Bogacheva, Spivak, 2019). Nevertheless, few generalized conclusions can be pointed out. The representatives of generation $\mathrm{Z}$ possess specific cognitive abilities (including the brain organization level). These differences do not represent any superpowers, which is obvious on all levels of pedagogical practice.

While the results of studies upon cognitive abilities of the digital aborigines are quite controversial, the studies of Internet use implications on the digital migrant cognitive abilities are sporadic. It is logical to assume that Internet use causes some implications. For instance, the idea that digital technology contains pathological factors was examined by A. Tkhostov and his colleagues (Tkhostov, Rasskasova \& Yemelin, 2019). Their research was based on a clinical study upon smartphone users with different levels of sleep disorder.

The results of some other studies may be interpreted in favour of the hypothesis mentioned above. Classic techniques used to study the thinking ( Objects Classification», "Pictogram», "Interpretation of proverbs») were applied to a group (C) Medvedskaia Elena

DOI (article): https://doi.org/10.32626/2227-6246.2021-54.78-92 
of 50 healthy people aged 20-39. The authors revealed specific features of consciousness and characterized them as «Psychopathology of Everyday Life" by analogy with the famous work of Z. Freud. These features include: a decline in critical judgment to one's results, a neurodynamic disorder (fatigue, concentration loss, professional impairment, etc.), inconsistent, diverse and egocentric thinking (Sultanova \& Ivanova, 2017).

A rapid integration of the Internet into daily life requires empirical tests of hypotheses about possible (positive, developing or negative, deforming) impact of the Internet on cognitive abilities of the digital migrants. It can be assumed that if an impact is negative, the first higher mental functions to suffer would be those that go through the longest formation period during ontogenesis.

Current study specifies global hypotheses on mediated memorization mentioned above as follows. If active Internet use has a deforming effect, it will affect the most complex part of the higher mental function and show up with the following symptoms:

- the deterioration of memorizing new concepts in comparison with well-known ones;

- the increase of mistakes in recalling abstract concepts in comparison with concrete ones.

\section{Research Objective}

The aim of the article is to present an experimental substantiation of cognitive deformity in adult active Internet users based on the material of mediated memorization.

\section{Objectives of the article}

1. Description of the modification of the pictogram technique.

2. Revealing the features of mediated memorization of words in adult active Internet users.

(C) Medvedskaia Elena

DOI (article): https://doi.org/10.32626/2227-6246.2021-54.78-92 


\section{Research methods and methodology}

Empirical test of the hypothesis mentioned above was accomplished through a quasi-experimental study. The Internet users form the experimental group and the respondents who prefer the printed coding system, the Reading Subjects, form the control group.

The study involved 70 respondents from young and middle age groups. All the respondents have higher education and represent spheres of intellectual labor (sphere of culture, education and healthcare). The division into groups was carried out through the interviewing aimed at identifying the information habits and preferable information system (digital or printed).

A study of mediated memorization was carried out via a modified version of the pictogram technique. The instructions ( TTo each word, draw something that will later help you recall it»), the time frame (1 hour) and the structure of the test (words were offered in random order) met the basic requirements for the method. The modification comprised two rows of words instead of one (16 words in each).

Corresponding to a traditional list for memorizing, the first row comprised well-known words and phrases: 1. Happy holiday. 2. Hard work. 3. Development. 4. Hope. 5. Poisonous question. 6. Happiness. 7. Warm wind. 8. Cheat. 9. Freedom. 10. Dark night. 11. Delicious dinner. 12. Doubt. 13. Separation. 14. Brave action. 15. Illness. 16. Wealth (Rubinstein, 2004: 161).

Apart from concrete and abstract concepts, the second row also included words with figurative meaning. The words from the second row were supplemented with definitions taken from the dictionaries of foreign words (Bulyko, 2007). 1. Reliable abaca (a rope made of banana fiber). 2. Invariance (the state of being constant, unchanging). 3. Precise jab (light straight punch in boxing made from a long distance). 4. Plebs (commoners). 5. Apperception (the process of understanding some(C) Medvedskaia Elena

DOI (article): https://doi.org/10.32626/2227-6246.2021-54.78-92 
DOI: https://doi.org/10.32626/2227-6246.2021-54

2021. випуск 54

thing perceived in terms of previous experience). 6. Incendiary cachucha (Spanish dance). 7. Travesty (artistic imitation usually grotesquely incongruous in style, treatment, or subject matter). 8. Mestization (a process of mixing human races). 9. Gentle crossbred (species of sheep). 10. Scriting (a technique of retelling complex concepts through visualizing). 11. Jeres (deviation from dogmas; figuratively - nonsense). 12. Delicious petit four (a cake). 13. Defeatism (an attitude of accepting, expecting, or being resigned to defeat). 14. Evaluation (assessment) 15. Abrakadabra (magic spell, figurative - nonsense). 16. Reverence (a slight lowering of the body with bending of the knees, figurative - an act of respect).

Data processing and analysis was carried out according to two parameters. First, a quantitative assessment of memorized words (correct/incorrect). Second, a qualitative analysis of associations: the ability to find a mediated image, it's certain or general pattern, the adequacy and meaningfulness of associations.

\section{Results and Discussion}

The results of preliminary conversation showed that the majority of the respondents $(46 \%)$ do not have any unambiguous preferences in media sources. They equally use both digital media and printed sources. This type of respondents was excluded from the following survey. The second largest group (28 people or $40 \%$ ) is the Internet users. They voluntarily deprived themselves of reading any printed sources in daily life (apart from professional duties). The smallest group is the reading subjects (10 people or $14 \%$ ). This fact raised a certain methodological problem.

An issue of balancing a quantitative composition of the control and the experimental groups was solved via a method of quasi-samples. A bigger group of the Internet users was randomly divided into two groups, 10 participants each. It allowed us to make a comparative analysis twice and juxtapose

(C) Medvedskaia Elena

DOI (article): https://doi.org/10.32626/2227-6246.2021-54.78-92 
DOI: https://doi.org/10.32626/2227-6246.2021-54

2021. випУСК 54

obtained results. To facilitate the analysis of the results, only one of the comparative studies was described comprehensively.

Quantitative assessment of the correctness

of memorization

Table 1 shows the age parameters of the participants and the number of mistakes in recalling 2 rows of words: familiar (row 1) and unfamiliar (row 2).

Table 1

The number of mistakes in memorized words in different groups

\begin{tabular}{|c|c|c|c|c|c|c|}
\hline \multirow{2}{*}{ № } & \multicolumn{3}{|c|}{ The Control Group } & \multicolumn{3}{c|}{ The Experimental Group } \\
\cline { 2 - 7 } & Age & Row 1 & Row 2 & Age & Row 1 & Row 2 \\
\hline 1 & 42 & 0 & 0 & 46 & 0 & 0 \\
\hline 2 & 45 & 1 & 6 & 48 & 0 & 1 \\
\hline 3 & 44 & 0 & 6 & 37 & 0 & 8 \\
\hline 4 & 40 & 0 & 0 & 49 & 1 & 6 \\
\hline 5 & 38 & 0 & 0 & 38 & 3 & 5 \\
\hline 6 & 48 & 0 & 0 & 40 & 0 & 2 \\
\hline 7 & 37 & 0 & 0 & 39 & 0 & 1 \\
\hline 8 & 46 & 0 & 0 & 46 & 0 & 3 \\
\hline 9 & 53 & 0 & 0 & 45 & 2 & 8 \\
\hline 10 & 52 & 0 & 0 & 42 & 1 & 7 \\
\hline & $\mathrm{M}=44.5$ & $\sum=1$ & $\sum=12$ & $\mathrm{M}=43$ & $\sum=7$ & $\sum=41$ \\
\hline
\end{tabular}

A brief glance through the table showed the reading subjects made fewer mistakes in memorizing both rows. The number of people in the control group who memorized the words from both rows correctly statistically had no significant difference $\left(\varphi=0.63\right.$ at $\varphi_{\text {crit. }}=1.64$ for $\left.p \leq 0.05\right)$. Among the Internet users, there were more respondents who memorized well-known words $\left(\varphi=2.5\right.$ at $\varphi_{\text {crit. }}=2.31$ for $\left.\mathrm{p} \leq 0.01\right)$.

The number of mistakes also differed in two groups. A number of mistakes of familiar words was statistically the same (C) Medvedskaia Elena

DOI (article): https://doi.org/10.32626/2227-6246.2021-54.78-92 
( $\mathrm{U}=34$ at the critical value of the Mann - Whitney criterion for a $5 \%$ error probability $U=27$ ). However, the number of mistakes of unfamiliar words was significantly different.

Similar results were obtained when comparing the data of the control group and the experimental group. The results are as follows: $30 \%$ made mistakes in memorizing familiar words and $70 \%$ in the second row. The Internet users made fewer mistakes in memorizing words (6 words in row 1 and 38 words in row 2). However, the revealed differences persist: in the control group, there were significantly more participants who reproduced familiar words correctly in comparison with unfamiliar ones $(\varphi=1.83, p \leq 0.05)$. There was no significant difference in memorizing familiar words with the reading subjects $(U=38, p>0.05)$, while the results in memorizing unknown words were statistically different $(U=18, p \leq 0.01)$.

It is essential to point out that the analysis did not reveal a correlation between the age of the respondents and the number of right answers (Pearson's coefficient, SPSS v. 19 program). Thus, this allows us not to take involutional processes as potential factors affecting the study into account.

\section{Qualitative analysis of associations}

Most of the participants had concrete, meaningful associations which were similar in both groups. Table 2 depicts examples of pictograms for the words with different meanings (concrete, abstract, with figurative meaning).

There was one mistake in each group in memorizing a phrase «poisonous question». A member of the CG used a "check mark» and failed to recall the meaning of a symbol. A member of the EG failed to make up any association at all. Some other abstract concepts (freedom -2 , happiness -1 , cheat - 1) challenged the members of the EG to create an association. In the framework of pathopsychological studies, this inability to create a symbolic mediated image is interpreted as

C Medvedskaia Elena

DOI (article): https://doi.org/10.32626/2227-6246.2021-54.78-92 
DOI: https://doi.org/10.32626/2227-6246.2021-54

2021. випуск 54

a concreteness of thinking and a difficulty of generalization, which is inherent with oligophrenia and epilepsy (Rubinstein, 2004: 163). In our case, it represented the individual characteristics of the respondents' thinking or fluctuations in their functional state in performing the method, rather than of the disruptions mentioned above.

Table 2

Examples of pictures that mediate the memorization of familiar words

\begin{tabular}{|c|c|}
\hline The Control Group & The Experimental Group \\
\hline \multicolumn{2}{|c|}{ Happy Holiday } \\
\hline $\begin{array}{c}\text { Balloons }-4 \\
\text { Firework }-3 \\
\text { Cake }-1 \\
\text { Flowers }-1 \\
\text { Emoji }-1\end{array}$ & $\begin{array}{c}\text { Balloons }-5 \\
\text { Cake }-2 \\
\text { Firework }-1 \\
\text { Cake }-1 \\
\text { Shot }-1\end{array}$ \\
\hline \multicolumn{2}{|c|}{ Development } \\
\hline $\begin{array}{c}\text { Arrow }-3 \\
\text { Book }-2 \\
\text { Spiral }-2 \\
\text { Sketch of a human, } \\
\text { increasing in height }-1 \\
\text { Egg - chicken }- \text { hen }-1 \\
\text { Wavy line }-1\end{array}$ & $\begin{array}{c}\text { Book }-3 \\
\text { Arrow }-2 \\
\text { Tree }-2 \\
\text { Ladder }-1 \\
\text { Computer }-1 \\
\text { Pen }-1\end{array}$ \\
\hline \multicolumn{2}{|c|}{$\begin{array}{l}\text { Poisonous Question } \\
\end{array}$} \\
\hline $\begin{array}{c}\text { A snake shaped as a question } \\
\text { mark }-4 \\
\text { Question mark }-2 \\
\text { Mushroom }-2 \\
\text { Skull and crossbones }-1 \\
\text { Check mark }-1 \\
\end{array}$ & $\begin{array}{c}\text { A snake shaped as a question } \\
\text { mark }-4 \\
\text { Question mark }-2 \\
\text { Mushroom }-2 \\
\text { Syringe }-1 \\
\text { No picture }-1 \\
\end{array}$ \\
\hline
\end{tabular}

Table 3 shows the examples of pictograms for the words from row 2. There is also a similarity of associations of unfamiliar words in both groups.

(C) Medvedskaia Elena

DOI (article): https://doi.org/10.32626/2227-6246.2021-54.78-92 
Examples of associations for mediated memorization of unfamiliar words

\begin{tabular}{|c|c|}
\hline The Control Group & The Experimental Group \\
\hline \multicolumn{2}{|c|}{ Reliable Abaka } \\
\hline $\begin{array}{c}\text { Cable (rope) }-7 \\
\text { Banana }-2 \\
\text { Lock }-1\end{array}$ & $\begin{array}{c}\text { Cable (rope) }-9 \\
\text { Banana }-1\end{array}$ \\
\hline \multicolumn{2}{|c|}{ Invariance } \\
\hline $\begin{array}{c}\text { Crystal }-4 \\
\text { House }-1 \\
\text { Grave }-1 \\
\text { Parallels }-1 \\
\text { Exclamation mark }-1 \\
\text { Arrow }-1 \\
\text { No picture- } 1\end{array}$ & $\begin{array}{c}\text { Crystal }-2 \\
\text { Mathematical formulas }-2 \\
\text { Spiral }-1 \\
\text { Parallel lines }-1 \\
\text { Wavy lines }-1 \\
\text { Arrow }-1 \\
\text { Infinity sign }-1 \\
\text { No picture }-1 \\
\end{array}$ \\
\hline \multicolumn{2}{|c|}{ Jeres } \\
\hline $\begin{array}{c}\text { Chaotic lines }-6 \\
\text { Bomb }-1 \\
\text { Head with a halo }-1 \\
\text { Apple }-1 \\
\text { Geometric abstraction }-1 \\
\end{array}$ & $\begin{array}{c}\text { Chaotic lines }-6 \\
\text { Question mark }-1 \\
\text { Head with horns }-1 \\
\text { Apple }-1 \\
\text { Geometric abstraction }-1\end{array}$ \\
\hline
\end{tabular}

Below there are phrases from Table 3 in a descending order according to a frequency of mistakes:

- a concrete term «reliable abaca» $(100 \%$ of recognition in both groups);

- a word with a figurative meaning «jeres» (one mistake in each group, it's the result of using geometrical forms, i.e. inane images);

- an abstract concept «invariance» (3 mistakes in the CG, 4 mistakes in the EG. The reason is associating the words with universal symbols: parallels, infinity sign, spirals, or inability to choose an image).

(C) Medvedskaia Elena

DOI (article): https://doi.org/10.32626/2227-6246.2021-54.78-92 
DOI: https://doi.org/10.32626/2227-6246.2021-54

2021. виПУСК 54

Analyzing the data, we discovered additional line for the study. The point of the additional direction was in detection of unknown words at min and max levels of memorization. Table 4 presents the number of mistakes made in memorizing words with concrete and abstract meaning.

Table 4

Mistakes in recalling concrete and abstract concepts

\begin{tabular}{|c|c|c|c|c|c|}
\hline \multirow{2}{*}{ Concrete concepts } & \multicolumn{2}{|c|}{$\begin{array}{c}\text { Group of } \\
\text { respondents }\end{array}$} & \multirow{2}{*}{$\begin{array}{c}\text { Abstract } \\
\text { concepts }\end{array}$} & \multicolumn{2}{c|}{$\begin{array}{c}\text { Group of } \\
\text { respondents }\end{array}$} \\
\cline { 2 - 3 } \cline { 6 - 7 } & CG & EG & & CG & EG \\
\hline Reliable abaca & 0 & 0 & Invariance & 3 & 4 \\
\hline Precise jab & 0 & 1 & Apperception & 2 & 5 \\
\hline Plebs & 1 & 1 & Mestization & 0 & 4 \\
\hline Cachucha & 0 & 0 & Scriting & 1 & 5 \\
\hline Travesty & 1 & 4 & Eres & 1 & 1 \\
\hline Gentle crossbred & 1 & 3 & Defeatism & 2 & 6 \\
\hline Delicious petit four & 0 & 2 & Evaluation & 0 & 3 \\
\hline Curtsy & 0 & 0 & Abrakadabra & 0 & 2 \\
\hline$\sum$ & 3 & 11 & & 9 & 30 \\
\hline
\end{tabular}

According to the data in Table 4, there were fewer mistakes in memorization of concrete concepts in comparison with abstract concepts in both groups. There was no significant difference between the groups in memorizing concrete concepts $\left(\mathrm{U}=19.5\right.$ at $\mathrm{U}_{\text {crit. }}=15$ for $\left.\mathrm{p} \leq 0.05\right)$. However, there was a significant difference in the number of memorized abstract concepts $\left(\mathrm{U}=6.5\right.$ at $\mathrm{U}_{\text {crit. }}=9$ for $\left.\mathrm{p} \leq 0.01\right)$.

\section{Conclusions}

A comparative analysis revealed following:

- recognition of familiar words was at the same high level in both groups;

(C) Medvedskaia Elena

DOI (article): https://doi.org/10.32626/2227-6246.2021-54.78-92 
- recognition of unknown words was significantly higher in the CG (the difference was measured by two parameters: the number of people who made a mistake, the number of mistakes);

- respondents of both groups successfully memorized unknown concrete words;

- the number of memorized unknown abstract concepts was significantly higher in the CG.

The analysis revealed an impairment in the mediated memorization ability of the Internet users. The impairment was detached specifically in memorization of abstract concepts. Thus, the hypothesis of a deforming impact of Internet use on the higher mental functions has been empirically proved.

\section{Literature}

Богачева Н.В., Спивак Е.В. Мифы о «поколении Z». Москва : НИУ ВШЭ, 2019. 64 c.

Булыко А.Н. Большой словарь иностранных слов. 35 тысяч слов. Москва : Мартин, 2007. 704 с.

Рубинштейн С.Я. Экспериментальные методики патопсихологии и опыт применения их в клинике. Практическое руководство. Москва : Апрель-Пресс: Изд-во Института психотерапии, 2004. 224 с.

Султанова А.С., Иванова И.А. К проблеме нормативных показателей в патопсихологической диагностике. Клиническая и специальная психология, 2017, 6 (2), 83-96. URL : https://psyjournals. $\mathrm{ru} /$ files/86348/Sultanova_Ivanova.pdf. DOI $10.17759 /$ psyclin. 2017060207.

Тхостов А.Ш., Рассказова Е.И., Емелин В.А. Психическое здоровье в контексте информационного общества: к вопросу об изменениях в патогенезе и патоморфозе заболеваний (на примере нарушений цикла «сон - бодрствование». Консультативная психология и пси хотерапия, 2019, 27 (3), 44-60. DOI 10.17759//cpp.2019270304.

Prensky, M. Digital natives, Digital immigrants. On the Horizon, 2001, 9 (5), 1-6. DOI 10.1108/10748120110424816.

\section{References}

Bogacheva, N.V., \& Spivak, E.V. (2019). Mify o «pokolenii Z» [Myths about "Generation $Z$ »]. Moskva : Vysshaia shkola ekonomiki [in Russian].

(C) Medvedskaia Elena

DOI (article): https://doi.org/10.32626/2227-6246.2021-54.78-92 
DOI: https://doi.org/10.32626/2227-6246.2021-54

2021. випуск 54

Bulyko, A.N. (2007). Bolshoi slovar inostrannykh slov [A large dictionary of foreign words]. Moskva : Martin [in Russian].

Rubinshtein, S.Ya. (2004). Eksperimentalnyie metodiki patopsikhologii $i$ opyt primeneniia ikh $v$ klinike. Prakticheskoie rukovodstvo [Experimental methods of pathopsychology and experience of their application in the clinic. A practical guide]. Moskva : Aprel-Press: Izd-vo Instituta psikhoterapii [in Russian].

Sultanova, A.S., \& Ivanova, I.A. (2017). K probleme normativnykh pokazatelei v patopsikhologicheskoi diagnostike [To the Problem of Normative Data in Pathopsychological Diagnostics]. Klinicheskaia $i$ spetsialnaia psikhologiia - Clinical Psychology and Special Education, 6 (2), 83-96. Retrieved from https://psyjournals.ru/files/86348/ Sultanova_Ivanova.pdf. DOI 10.17759/psyclin.2017060207 [in Russian].

Tkhostov, A.Sh., Rasskazova, E.I., \& Emelin, V.A. (2019). Psikhicheskoie zdorovie $\mathrm{v}$ kontekste informatsionnogo obshchestva: $\mathrm{k}$ voprosu ob izmeneniiakh $\mathrm{v}$ patogeneze i patomorfoze zabolevanii (na primere narushenii tsikla «son - bodrstvovaniie» [Mental health in the context of information society: to the issue of changes in the pathogenesis and pathomorphism of diseases (on the model of disturbances of the sleep - wake cycle)]. Konsultativnaia psikhologiia $i$ psikhoterapiia - Consultative Psychology and Psychotherapy, 27 (3), 44-60. DOI 10.17759//cpp.2019270304 [in Russian].

Prensky, M. (2001). Digital natives, Digital immigrants. On the Horizon, 9 (5), 1-6. DOI 10.1108/10748120110424816.

\section{Медведська Єлєна. Особливості опосередкованого запам'ятовування у дорослих активних інтернет-користувачів}

\section{АНОТАЦІЯ}

Meта cmammi - описати особливості опосередкованого запам'ятовування слів (знайомих / малознайомих, що позначають конкретні / абстрактні поняття) у дорослих активних інтернет-користувачів.

Методи. Дослідження здійснено у вибіриі із 70 респондентів віком від 37 до 53 років. Усі учасники мають вищу освіту, працюють у сфері інтелектуальних професій (працівники установ освіти, культури й охорони здоров'я). Із загальної вибірки за допомогою бесіди було диреренційовано дві групи, що відрізняються за своїми уподобаннями провідною системою кодування інформації: активні інтернет-користувачі (експерименталь(C) Medvedskaia Elena

DOI (article): https://doi.org/10.32626/2227-6246.2021-54.78-92 
DOI: https://doi.org/10.32626/2227-6246.2021-54

2021. ВИПУСК 54

на група) і суб'єкти, які читають (контрольна група), що зберігають у своїй життєдіяльності звичку до читання паперових носіїв.

Вивчення опосередкованого запам'ятовування проводилося за допомогою методики піктограми з модифрікачією у вигляді другого ряду для запам'ятовування, що складається з іноземних, малознайомих слів. ІІнструкція, час перевірки правильності пригадування і його порядок були ідентичні в двох випадках і відповідали базовим вимогам до методики.

Результати дослідження. Установлено, що в пригадуванні знайомих слів дані двох груп тотожні. Статистично достовірні відмінності $(p \leq 0,01)$ виявлено у відтворенні малознайомих понять, де меншу кількість помилок продемонстрували суб'єкти, які читають. Усередині цього ряду малознайомих понять у респондентів двох груп виявлено значущі відмінності $(p \leq 0,01)$ у правильному пригадуванні абстрактних понять. Тут також меншу кількість помилок зафіксовано у суб'єктів, які читають. У результаті кореляційного аналізу не встановлено зв'язків між кількістю помилок пригадування і віком респондентів у експериментальній і контрольній групах.

Висновки. Емпірично підтверджено гіпотезу про деформуючий вплив активних інтернет-практик на опосередковане запам'ятовування. Ця дерормація полягає у погіршенні здатності до запам'ятовування нової інформації, особливо якщо вона має узагальнений характер.

Ключові слова: вищі психічні функції, опосередковане запам'ятовування, піктограма, активні інтернет-користувачі.

\section{Медведская Елена. Особенности опосредованного запоминания у взрослых активных интернет-пользователей}

\section{АННОТАЦИЯ}

Цель статьи - описать особенности опосредованного запоминания слов (знакомых / малознакомых, обозначающих конкретные / абстрактные понятия) у взрослых активных интернет-пользователей.

Методы. Исследование осуществлено в выборке из 70 респондентов в возрасте от 37 до 53 лет. Все участники имеют высшее образование, работают в сфере интеллектуальных профессий (работники учреждений образования, культуры и здравоохранения). Из общей выборки посредством беседы было дифрференцировано две группы, отличающихся по своим предпочтениям ведущей системой кодирования информации:

(c) Medvedskaia Elena

DOI (article): https://doi.org/10.32626/2227-6246.2021-54.78-92 
DOI: https://doi.org/10.32626/2227-6246.2021-54 2021. випуск 54

активные интернет-пользователи (экспериментальная группа) и субъекты читающие (контрольная группа), сохраняющие в своей жизнедеятельности привычку к чтению бумажных носителей.

Изучение опосредованного запоминания проводилось посредством методики пиктограммы с модификацией в виде второго ряда для запоминания, состоящего из иностранных, малознакомых слов. Инструкция, время проверки правильности припоминания и его порядок были идентичны в двух случаях и соответствовали базовым требованиям к меподике.

Результаты исследования. Установлено, что в припоминании знакомых слов данные двух групп тождественны. Статистически достоверные различия ( $p \leq 0,01)$ обнаружены в воспроизведении малознакомых понятий, где меньшее количество ошибок продемонстрировали субъекты читающие. Внутри этого ряда малознакомых понятий у респондентов двух групп выявлены значимые отличия ( $p \leq 0,01)$ в правильном припоминании абстрактных понятий. здесь также меньшее количество ошибок зафиксировано у субъектов читающих. В итоге корреляционного анализа не установлено связей между количеством ошибок припоминания и возрастом респондентов в экспериментальной и контрольной группах.

Выводы. Эмпирически подтверждена гипотеза о деформирующем влиянии активных интернет-практик на опосредованное запоминание. Данная деформация заключается в ухудшении способности к запоминанию новой информации, особенно если она имеет обобщенный характер.

Ключевые слова: высшие психические функции, опосредованное запоминание, пиктограмма, активные интернет-пользователи.

Original manuscript received August 15, 2021

Revised manuscript accepted September 29, 2021

(C) Medvedskaia Elena

DOI (article): https://doi.org/10.32626/2227-6246.2021-54.78-92 